\title{
Diary of A Restless Teacher: How We Can Shift to The Learner- Centered Approach
}

\author{
Mohini Vidwans
}

Faculty of Agribusiness and Commerce, Lincoln University, New Zealand

\begin{tabular}{ll} 
ARTICLE INFO & ABSTRACT \\
\cline { 2 - 2 } $\begin{array}{l}\text { Keywords: } \\
\text { Social Constructivist } \\
\text { Technology }\end{array}$ & $\begin{array}{l}\text { Beyond doubt, learner-centered approach has proved to be } \\
\text { effective for better learning outcomes. Drawing on a personal } \\
\text { experience, I present in this paper how a mix of being involved }\end{array}$ \\
with a series of training workshops, discussion with my \\
colleagues, and the 'accidental' introduction of social \\
constructivist tools in my classrooms gradually changed my \\
view on the potential of technology in the learning process. It \\
also looks at how a reflective diary helped me to leverage these \\
experiences more effectively. It records a journey of interaction \\
with education designers, other teachers and students, and how \\
I selected the resources and approaches that might produce \\
better learning opportunities for the learners. It further looks at \\
the adoption of learning technology as a vehicle for developing \\
the teacher's own understanding of the power of social \\
learning. I address some of the challenges I encountered while \\
making the shift. The paper concludes that intentionally \\
reviewing one's teaching in collaboration with education \\
experts, one's colleagues and learners is a positive experience \\
and has resulted in an approach that has considerably shifted \\
the focus to learners. I am optimistic that my fellow teachers \\
find my experiences inspiring and we collectively can bring \\
about a change for the benefit of the education sector.
\end{tabular}

\section{Introduction}

Like most other tertiary academics, I received no formal training as a teacher. I vividly remember, when I delivered my first lecture in 1996 the main resources were a notebook and a blackboard. 'Teaching' consisted of my doing almost all of the talking. Later I learnt this is called teacher-centric approach. Before long I graduated to teaching with an overhead projector and then for many years the dominant technology in my classrooms was PowerPoint. Looking back now, I see that embedded in that technology was the pedagogy of teacher-as-the-authority. Each time I used it; the pedagogy of teacher-centeredness was reproduced. My learners were there for me to pour information into. How they might process that information did not occur to me, neither was there any technology that offered me that choice. PowerPoint constrained my understanding of the learning to information transfer. Fast forward to 2019, I consider myself a resourceful teacher who values student talk, learner decision-making in the class and group work as indicators of learning in action. Various factors have contributed to the adoption of this learner-centric approach-constant reflection, support from the university education

* Corresponding Author E-Mail Address: Mohini.Vidwans@lincoln.ac.nz 
design team and dramatically improved learning technology among them. The journey I share with you here comes from notes I made along the way.

\section{The Evolution}

Six years ago, I came to my current university where the learning management system, Moodle, was an established vehicle in most courses. Like most of my colleagues, past and present, I felt most comfortable with Moodle when I used it to transfer information, doing what I have always done with PowerPoint, but in a more sophisticated way. I was not aware of, nor was I inspired to explore the radically different way of teaching the resources the Moodle technology offered. I gave students instructions on how to upload their assignments, where to find the lecture notes I wanted them to read, when the assignment deadlines were. Nonetheless, I made the initial shift of delegating power to the students about when they could access the resourcesPowerPoint was available for them to view at a time suitable to them, recorded lectures posted on Moodle enabled them to revisit the discussion, this sharing of authority over resources gave them more autonomy. By accident, I had started giving the students power and an opportunity to construct their own meaning, though in a limited way.

Moodle has a different pedagogy in its design and I began to get a feel for this when I added a few quizzes and crosswords that required students to test out the knowledge they had acquired in our class. When I saw how much they enjoyed even these limited activities I began to explore other tools and ideas. Again, the technology and the student response to it was a vehicle for changes in my thinking. They liked the ability to choose their own groups for collaborative assignments that Moodle 'group-selection' offered. They liked that they did not have to print off the submission and physically drop a hard copy in the drop box. They could share ideas with each other through student forum. Without my being much aware of it, the technology had begun to shift the power in my classroom using the social constructivist approach (Hein, 1991).

Teaching a large class of 122 students in 2016 was a defining moment for me. In the classroom cum-auditorium on Day One of a course I was taking, all I could see was a sea of faces. I could not connect with them. My discomfort was sensed by an exchange student-teacher from the Netherlands. After class he introduced me to Kahoot. That same evening, I registered for the online polling tool, made a simple quiz and used it in the class on the following day. It helped me in connecting with the class: I felt a confidence I was addressing the gap between us; I could see they were engaged, there was a buzz, a positive energy in the room that had not been there the day before. I began to see what collaboration might be about in practical terms. The technology was a springboard to learning - my own and the students. It contributed to firing up the students, to making me feel I was making a difference. It was novel to them, and to me. A fresh classroom. The old paradigm was fractured if not broken. The fracture proved a common ground for us all. This did not happen overnight; it was a gradual process. My evolution of over two decades is presented in Fig. 1.

My thinking changed with each bit of technology that was added to the resources I used. At the outset, I was embedded in the teacher-centric mode, but in-class and out-of-class interactive platforms enabled by the technology, pushed me further away from the traditional mode. It was an iterative process.

In January 2019 things took a big step forward. I got an opportunity to develop and deliver a new course. I began reflecting on the aspiration I had for my prospective learners and to share this with a couple of colleagues. As part of the process, I began to make notes about ideas I had and as time went along I found these very useful and before I knew it I was writing a regular 'diary' of the ideas, experiences and people I shared these with (Kuit, Reay and Freeman, 2001). I was keen to explore how I could adapt my pedagogy to the unique needs of my learners, by using the web, re-allocating class time and other resources for effective learning 
outcomes. A few weeks later I opened the first iteration of the new course with my students. By then, I had already had some useful activities to try out. These came out of my reflections and some training provided around a grant.

As a grant recipient I received financial and pedagogical support which was extremely useful. I worked with content writers to develop a glossary and scenario-based question bank. As I gave these to my students, I tried to gather data from them about how useful new tools and activities were. At the same time, I participated in five workshops organized by the education design team at the university from March to May. These facilitated the exploration of blended learning approaches and collaborative learning with fellow teacher-participants. Importantly, I documented my journey in the diary and the deliberations helped me in making necessary changes in the following weeks and also planning the next delivery of the course in 2020.

\section{The shift to the learner-centered approach}

At a previous university, one of my colleagues exasperated with the distractions in the class, used to keep a bucket for the students to deposit their cell phones for the duration of the period. At the time, I doubted whether the 'bucket methodology' helped increase learner engagement. My own journey since then suggests we have to accept that the technology in the classroom is here to stay and it can be a positive means to enhance the learning experience. Although technology itself cannot change things, some current technology has tremendous potential to engage students because learner-centeredness is embedded in its configuration.

We have to be open minded, enthusiastic and courageous to venture into the unknown. Over the years I have explored and used a variety of tools to enhance student engagement (see Figure 1). It has been a collaborative effort with the education design team at the university, colleagues and students. One of my main aspirations has been to build a collaborative learning culture that bridges face-to-face and online modalities. Recognizing that learning is largely a social process it is important to prioritize students' needs and their agency in learning activities. When students are in a face-to-face class session, I want them to focus on interaction with each other. Learning is about two things, according to Mazur (2013): information transfer and information processing. I want my students to spend the time they are physically together sharing their understanding of a concept, trying out new ideas, questioning each other. That is, information processing.

That means I need to put the information transfer part into the online mode where I can. One aspect of the practice of being learner-centric in the classroom I am acutely aware of these days is the need to substantially reduce the teacher-talk time in the classroom: and to facilitate more student-to-student interaction and active learning (Yerigan, 2008). Introducing short online activities in my face-to-face class time has significantly changed the balance of who talks in class. Over the past few years some free-to-use online applications that are designed around social constructivism have helped me implement this aspiration. Importantly for me, in deploying them in my classes, my understanding of what learner-centeredness is has grown (Huba and Freed, 2000). I am moving from being the sage-on the stage to the guide-on-theside (King, 1993). Using technology has been a vital aspect of my growing understanding of learner agency and control. Some examples of applications I have used that embody learnercenteredness in their various constructs are illustrated below (Figure 1). 


\section{Learner centric approach}

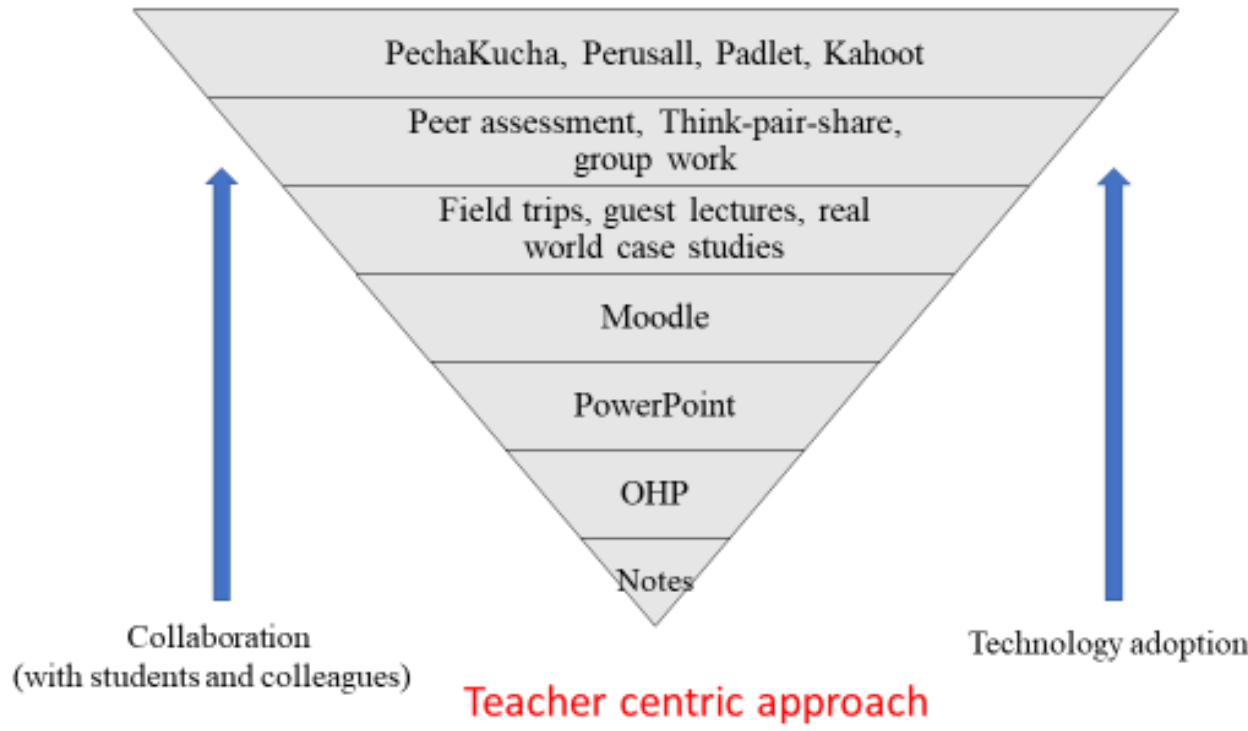

Figure 1. Shift to the learner-centered approach

- Kahoot: Initially I used Kahoot (https://kahoot.com/) as a means to connect to a large class, but I soon recognized its potential as an excellent motivational and feedback tool. The lecturer and the students get instant feedback on the responses they have offered and any doubts can be cleared then and there. I also use it for student collaboration and discussion. I have used it as a survey tool, for gathering their opinions, and for formal assessments. The application also creates a competitive spirit in the class as the students know who the top five responders are after every answer.

- Padlet is an excellent way of sharing the class whiteboard with students (https://padlet.com/) which traditionally has been the domain of the teacher. In large classes it gives the students an opportunity to voice their opinions in a safe way. They prefer this to standing up individually in the class to make a point or offer an answer. Padlet can be used to combine the teacher-centric and learner-centric approach. Recently I discussed SWOT analysis which is about identifying strengths, weaknesses, opportunities and threats. Then in groups the class analysed a case study using SWOT and uploaded their analysis on Padlet which they presented in the class. The Padlet link was integrated into Moodle so that they had access to the analyses even after the class.

- Perusall is an online reading application that creates collaborative learning environments conducive to students taking responsibility for their own learning by commenting on the assigned article and also responding to other's comments (https://perusall.com/). I participated in a pilot study of Perusall at the university. Inspired by the experience, I was the first one on campus to adopt it for a course. Initially apprehensive about the new tool, the students enjoyed the experience. I organized a feedback session which gave them an opportunity to review this new experience and share their views with others and with me. Some of the points they made were:

Good for engaging with other students, we can easily talk to each other, very interesting, was a bit confusing about what to do to begin with but once started 
it made sense, cool to see other students' opinions, good to get class discussion, useful for learning because sometimes we do not speak in class.

- PechaKutcha: I came across this novel style of oral presentations (https://www.pechakucha.com/) when I attended an art and craft event. In PechaKucha presentation format the presenter uses 20 images, each for 20 seconds. The images advance automatically and you talk along to the images. Recognizing its potential to increase student engagement, I immediately decided to use it in the class, the students enthusiastically accepted the challenge (many of them hadn't heard of this style). Aware of the time pressure I slightly modified the format with 20 images each for 30 seconds. Keen to know about their experience, I held a brief feedback session after the presentations where I asked them to share information about the positive and negative points. The positive comments were - teamwork, confidence, exciting, fair (as everyone works within the same framework), and use of images. The challenging bits were that it was rigid, they had less control, and it was stressful to keep up with the automatic advancing of slides. But overall, they enjoyed the novel experience.

The workshops I participated in taught me that engaging students does not need to be about technology alone. Simple ways of thinking about how I organize the student activities can readily increase their efficacy. Here are some I noted in my diary:

- Think-pair-share: Though an old approach (King, 1993; McTighe and Lyman, 1988), this is an effective way of reducing teacher-talk time and building learner confidence (Kaddoura, 2013). It breaks the monotony of the teacher's voice and creates a collaborative opportunity for the students to share and learn from each other. I saw this approach being effectively implemented at a workshop I attended on blended learning. The facilitator had a colleague sitting at the back recording the length of time of each of his contributions to the session and the length of time the students controlled the conversation. At the end, the time report was presented, the facilitator used only about $15 \%$ of the session time, and the rest of it was we participants, thinking and sharing our ideas. No wonder the session was energizing and a great learning experience.

- Lab sessions/workshops: We all know that 'doing is the best way of learning'. Lab sessions are not new to people in science, but my background being business management, I never had an experience of working in a lab. My senior colleague showed me that if designed well, labs can be used for any subject for providing a practical experience. It basically facilitates practical learning with an opportunity to solve problems and make decisions about real products, services, processes, and people. Now I use labs regularly_-small groups are presented with a specific problem related to a topic covered in the previous week/s and at the end of the three hour session they submit a report.

- Along with the tools I have mentioned for increasing engagement with the real-world, I use relevant current events, videos, field trips, case studies and guest presentations. This stimulates interest and curiosity, and enables active interaction with information that can be connected to course concepts. It is crucial to demonstrate to the students that their learning is relevant and not limited to the classroom.

My reflective diary was not only an effective way of tracking the efficacy of the technology we were using in class, it also prompted me to use "stop and check" ideas I was experimenting with. I noted the things that worked or did not work and what I could change. For example, I saw that the students struggled writing a test on paper as computers have largely replaced notebooks and they are not used to writing on paper. So, I discussed this with them and for the second test I gave them the option of online test. Of the 28 students, 22 opted for online and remaining six preferred paper and pen. Students were happy to be able to use their agency and 
voice, and for me it made the marking considerably easier as I did not have to spend time in deciphering their handwriting!

Student evaluations at the end of the new course indicated that they found the learning experience valuable. Here are some instances:

The variety of learning material was outstanding especially in comparison to other courses.

Courses resources were variable, interesting, and excellent.

I love the Kahoot quiz and pair assignment, and although I think the tests are a bit difficult for me, it's still a good way of learning.

Many examples were used including guest speakers who gave us an indication of what is presently being experienced in the workforce and what methods are being used to enhance or make the challenge more manageable.

\subsection{Challenges}

Technological resources can facilitate collaboration between online and offline modalities, but is not a panacea. We have to heavily invest in the effort. Flexibility and harmonious balance are crucial in the process. Generally, students are used to the sage-on-the-stage approach, so they need to be trained in actively participating in the different activities. For example, I used self and peer assessment function of Moodle in one of my courses, and after the first assignment I realised that they were not comfortable doing it as they had never received any training in assessing self and/or others. So, I made a quick point in my diary about training them before introducing a new activity. Also, sometimes because of time and other pressures it is difficult for the teacher to be focused on learner-centric approach. The staff development grant I received helped me significantly in getting access to the necessary resources. Another caveat is the various tools should be used sparingly, wisely, making sure that they suit the pedagogical purpose of the activity. After I gave a presentation on Kahoot at Show-and-tell at the university, some of my colleagues started using it. So, it was important for me to not to overuse it.

\section{Conclusion}

My quest for a learner-centric approach and my reflections on the experience, coupled with technological and pedagogical support at the University made the journey effective and productive. With the help of appropriate technology, I can provide students with choices about time and place of learning - where practical, they can decide where, when and how they learn. In my own case this has happened largely because of the shift in me-from the teacher-centric to learner-centric approach. Possibly, as Liu and Geertshuis (2016) argue the learning technology aligned with my pedagogical beliefs enacted a dormant desired teaching approach and my professional identity changed over time. Over the last few years, I learnt how learnercentered approach can be developed with the help of technology and maintaining a diary significantly helped in reflecting on what worked, what did not, and how it can be modified next time. Intentionally reviewing one's teaching in collaboration with education experts, one's colleagues and learners has been a positive experience in shifting the focus on to my learners.

\section{Acknowledgment}

This paper is an output of the blended grant I received at my university; I am grateful to the blended team for the inputs. Particularly, I am thankful to Dr Maurice Ward for the valuable support and his comments on this paper. 


\section{References}

Hein, G.H. (1991). Constructivist Learning Theory. The Museum and the Needs of People. CECA (International Committee of Museum Educators) Conference. Jerusalem, Israel, 1522 October 1991, https://www.exploratorium.edu/education/ifi/constructivist-learning

Huba M.E. \& Freed J.E. (2000). Learner-centered assessment on college campuses: Shifting the focus from teaching to learning. Pearson.

Kaddoura, M. (2013). Think pair share: A teaching learning strategy to enhance students' critical thinking. Educational Research Quarterly, 36(4), 3-24.

King, A. (1993). From sage on the stage to guide on the side. College teaching, 41(1), 30-35.

Kuit, J. A., Reay, G., \& Freeman, R. (2001). Experiences of reflective teaching. Active learning in higher education, 2(2), 128-142.

Liu, Q. \& Geertshuis, S. (2016). Professional identity and teachers' learning technology adoption: a review of adopter-related antecedents. Show Me The Learning. Proceedings ASCILITE, 365-374.

Mazur (2013). Interview. Available https://www.seas.harvard.edu/news/2013/03/flippedclassroom-will-redefine-role-educators

McTighe, J. and Lyman, Jr., F.T. (1988), "Cueing Thinking in the Classroom: The Promise of Theory-Embedded Tools".

Available http://www.ascd.org/ASCD/pdf/journals/ed_lead/el_198804_mctighe.pdf

Yerigan, T. (2008), "Getting Active In The Classroom", Journal of College Teaching and Learning, Vol. 5, Issue 6, pp. 19-24. 